\title{
用語解説
}

\section{メビウス反転（Möbius Inversion）}

メビウス反転は，ファジィ測度 (集合に值を割り当てる集合関数の一種)の別表現である.ファジィ測度 $\mu$ は, 複 数の要素が集まった効果などを表す。例えば，1時間あたりの作業員 aの作成量 $10 \mathrm{~kg}, \mu(\{\mathrm{a}\})=10, \mathrm{~b}$ は $\mu(\{\mathrm{b}\})=$ 15,2 人が協力し単独の和より $5 \mathrm{~kg}$ 多い $\mu(\{\mathrm{a}, \mathrm{b}\})=30$ のような非加法的な関係 $\mu(\{\mathrm{a}, \mathrm{b}\}) \lessgtr \mu(\{\mathrm{a}\})+\mu(\{\mathrm{b}\})$ を表現できる.

メビウス反転 $\delta$ は, ファジィ測度 $\mu$ の増分をとりだす集合関数である. 単独の増分 $\delta(\{a\})=10, \delta(\{b\})=15$ と a, $\mathrm{b}$ 協力の増分 $\delta(\{\mathrm{a}, \mathrm{b}\})=5$ となる. ファジィ測度 $\mu(\mathrm{A})$ の值は, $\mu(\{\mathrm{a}, \mathrm{b}\})=\delta(\{\mathrm{a}\})+\delta(\{\mathrm{b}\})+\delta(\{\mathrm{a}, \mathrm{b}\})$ のよう

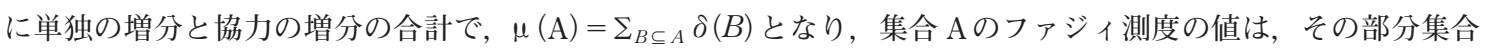
のメビウス反転の值の合計となる。逆に，ファジィ測度からメビウス反転は， $\delta(\mathrm{A})=\Sigma_{B \subseteq A}(-1)^{(n-m)} \mu(B)$ と定 義されている $(\mathrm{n}, \mathrm{m}$ は，それぞれ集合 $\mathrm{A}, \mathrm{B}$ の要素数). 3 人の作業員 $(\mathrm{a}, \mathrm{b}, \mathrm{c})$ の協力による増分は, $\delta(\{\mathrm{a}, \mathrm{b}, \mathrm{c}\})=$ $\mu(\{\mathrm{a}, \mathrm{b}, \mathrm{c}\})-\mu(\{\mathrm{a}, \mathrm{b}\})-\mu(\{\mathrm{a}, \mathrm{c}\})-\mu(\{\mathrm{b}, \mathrm{c}\})+\mu(\{\mathrm{a}\})+\mu(\{\mathrm{b}\})+\mu(\{\mathrm{c}\})$ となる.

ファジィ測度とメビウス反転の集合関数は 1 対 1 対応するので，ファジィ測度をメビウス反転で解釈したり， メビウス反転からファジィ測度を求めたりすることができる。また,ゲームの理論など使われるシャプレィ值は, 要素数 (人数)に応じたメビウス反転の值の合計で表現できる. 3 人の場合の作業員 aのシャプレィ值は， $\delta(\{a\})$ $+(1 / 2)[\delta(\{\mathrm{a}, \mathrm{b}\})+\delta(\{\mathrm{a}, \mathrm{c}\})]+(1 / 3) \delta(\{\mathrm{a}, \mathrm{b}, \mathrm{c}\})$ となり, 各増分をその集合の要素の作業員で分けるという解 釈になる。逆にファジィ測度の単調性制約 $(\mathrm{A} \subseteq \mathrm{B}$ ならば $\mu(\mathrm{A}) \leq \mu(\mathrm{B}))$ はメビウス反転では表現しづらい.

メビウス反転を使ったショケ積分は，入力值を $\mathrm{h}(\mathrm{a}), \mathrm{h}(\mathrm{b}), \ldots$ とすると， $\Sigma_{A} \wedge_{x \in A} \delta(A)$ となる. 2 要素の場 合の $h(a) \delta(\{a\})+h(b) \delta(\{b\})+\min (h(a), h(b)) \delta(\{a, b\})$ のように入力值を降順に並べ替えずに計算できる.

メビウス反転の数学的な解説は, 本誌 10 巻 2 号, 16 巻 4 号にある.

(専修大学 商学部 高萩 栄一郎)

\section{ファイブフォース分析 (Five Forces Analysis)}

マイケル・E・ポーターは，その著書『競争の戦略 (Competitive Strategy)』の中で，業界内での競争状態を決 めるのは，基本的に 5 つの要因であることを示し，この 5 つの競争要因から業界の構造分析を行うことを提案し たそそして，この技法がファイブフォース分析と呼ばれるようになった，ここでいう業界とは，互いに代替可能 な製品やサービスを作っている，あるいは提供している企業の集団のことである．また，5つの競争要因は，「新 規参入業者の脅威」「既存競争企業間の敵対関係」「代替品の脅威」「買い手の交渉力」「売り手の交渉力」である. 例 えば，「新規参入業者の脅威」では，(1)規模の経済性，(2)製品の差別化，(3)巨額の投資，(4)仕入先変更コスト，(5) 流通チャネルの確保，6規模とは無関係なコスト面での不利，(7)政府の政策・法律による規制などの参入障壁に ついて分析する．また，過去に参入業者に対する既存業者からの報復があったか，参入を抑える価格になってい

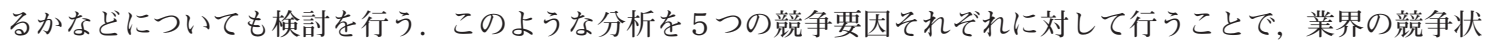
態を分析することができる，ファイブフォース分析により，業界内の競争に影響を及ぼしている要因とその根底 にある原因を突き止めれば，業界内に打ける自社の位置(Position) あるいはこれから参入しようとする業界内で の位置を確認し，自社の強及と弱みを見つけることができる. 効果的な競争戦略は，5つの競争要因に対して， 防御できる位置をつくり出すための攻めのアクション，あるいは防御のアクションをとることである。そして， 防御可能な位置をつくるためには，3つの基本戦略:コストリーダーシップ戦略，差別化戦略，集中戦略がある.

なお，ポーターの経営戦略論は，第 1 世代 (業界選択) と呼ばれ，バーニーの RBV (Resource-Based View)に よる経営戦略論が第 2 世代 (個別企業の内部資源) と呼ばれている. 第 1 世代と第 2 世代で, 企業業績のばらつき の約 $60 \%$ が説明できるとされており，残り $40 \%$ を説明する理論として，不確実性を重視する経営戦略論(第 3 世代)が登場する。して現在，これらに分類されない経営戦略論も議論されている.

(近畿大学 経営学部 経営学科 古殿 幸雄) 